Jurnal Akuntansi AKTIVA, Vol 1, No 2, Oktober 2020

\title{
PENGARUH UPAH MINIMUM PROVINSI, PDRB DAN INVESTASI TERHADAP PENYERAPAN TENAGA KERJA SEKTOR INDUSTRI DI PULAU JAWA TAHUN 2010-2016
}

\author{
Desy Meilasari \\ Universitas Lampung, Jl. Prof. Dr. Ir. Sumantri Brojonegoro, 35141, Bandar Lampung, Indonesia
}

desymeila90@gmail.com

\begin{abstract}
This research aims to analyze the effect of provincial Minimum wage (UMP), PDRB, and investment in the industrial sector of labor absorption on Java island in 2010-2016. Data used is a data panel consisting of data time series 2010 - 2016 and cross section six provinces namely DKI Jakarta, West Java, Central Java, IN Yogyakarta, East Java, and Banten. The Anaalisis tool used is a data regression panel i.e. Fixed Effect Model (FEM). The results showed that UMP has a significant effect on the labor absorption of the industrial sector on Java Island in 2010-2016. While the PDRB and investment have a positive and significant effect on the labor absorption of industrial sectors in Java Island in 2010-2016. Through this research, the government expects more cautious and creating a conducive investment climate so that the value of PDRB is increasing.
\end{abstract}

Keywords: Minimum Provincial Wages (UMP), GDRP, and Investment.

\begin{abstract}
ABSTRAK
Penelitian ini bertujuan untuk menganalisis pengaruh Upah Minimum Provinsi (UMP), PDRB, dan investasi terhadap penyerapan tenaga kerja sektor industri di Pulau Jawa tahun 2010-2016. Data yang digunakan merupakan data panel yang terdiri dari data time series tahun 2010- 2016 dan cross section enam Provinsi yaitu DKI Jakarta, Jawa Barat, Jawa Tengah, DI Yogyakarta, Jawa Timur, dan Banten. Alat anaalisis yang digunakan adalah regresi data panel yaitu Fixed Effect Model (FEM). Hasil penelitian menunjukkan bahwa UMP berpengaruh negatif dan signifikan terhadap penyerapan tenaga kerja sektor industri di Pulau Jawa tahun 20102016. Sedangkan PDRB dan investasi berpengaruh positif dan signifikan terhadap penyerapan tenaga kerja sektor industri di Pulau Jawa tahun 2010-2016. Melalui penelitian ini diharapkan pemerintah lebih berhati-hati dalam menentukan UMP, serta menciptakan iklim investasi yang kondusif sehingga nilai PDRB lebih meningkat.
\end{abstract}

Kata Kunci: Upah Minimum Provinsi (UMP), PDRB, dan Investasi. 


\section{PENDAHULUAN}

Penyerapan tenaga kerja merupakan salah satu faktor fundamental dalam mencerminkan kondisi perekonomian yang dinamis. Penyerapan tenaga kerja juga tidak lepas dari peranan pemerintah dalam penyusun kebijakan dalam meningkatkan tingkat kesejahteraan tenaga kerja. Pemerintah memiliki andil yang sangat kuat dalam menentukan kebijakan dalam mencapai pertumbuhan ekonomi yang tinggi. Penyerapan tenaga kerja atau biasa disebut sebagai pro-job menjadi agenda penting selain pro-poor (pengentasan kemiskinan, dan pro-growth (peningkatan pertumbuhan) (Kuncoro,2002:73). Penyerapan tenaga kerja dipengaruhi oleh berbagai faktor antara lain adalah pendapatan nasional, tingkat investasi, dan upah tenaga kerja. Perubahan pada faktorfaktor tersebut akan mempengaruhi tingkat penyerapan tenaga kerja.

Menurut ekonom klasik seperti Adam Smith, David Ricardo dan Thomas Robert Malthus menyatakan bahwa selalu ada perlombaan antara tingkat perkembangan output dengan tingkat perkembangan penduduk yang akhirnya dimenangkan oleh perkembangan penduduk. Karena penduduk juga berfungsi sebagai tenaga kerja, maka akan terdapat kesulitan dalam penyediaan lapangan pekerjaan. Jika penduduk itu dapat memperoleh pekerjaan, maka hal ini akan dapat meningkatkan kesejahteraan bangsanya. Tetapi jika tidak memperoleh pekerjaan berarti mereka akan menganggur, dan justru akan menekan standar hidup bangsanya menjadi lebih rendah (Irawan dan Suparmoko, 2002).

Masalah ketenagakerjaan bukan hanya sekedar keterbatasan lapangan atau peluang kerja serta rendahnya produktivitas namun jauh lebih serius dengan penyebab yang berbeda-beda. Masalah pokok dalam ketenagakerjaan tertumpu pada kegagalan penciptaan lapangan kerja yang baru pada tingkat yang sebanding dengan laju pertumbuhan output industri. Seiring dengan berubahnya lingkungan makro ekonomi mayoritas negara-negara berkembang, angka pengangguran yang meningkat pesat terutama disebabkan oleh "terbatasnya permintaan" tenaga kerja, yang selanjutnya semakin diciutkan oleh faktor-faktor eksternal seperti memburuknya kondisi neraca pembayaran, meningkatnya masalah utang luar negeri dan kebijakan lainnya, yang pada gilirannya telah mengakibatkan kemerosotan pertumbuhan industri, tingkat upah, dan akhirnya, penyediaan lapangan kerja (Todaro, 2000).

Salah satu usaha yang dilakukan oleh pemerintah dalam mengatasi masalah ketenagakerjaan yaitu memperbaiki sistem upah melalui kebijakan upah minimum. Penerapan kebijakan upah minimum merupakan usaha dalam rangka meningkatkan upah pekerja sehingga tingkat upah rata-rata tenaga kerja dapat meningkat. Kebijakan upah minimum merupakan sistem pengupahan yang telah banyak diterapkan di beberapa negara, yang pada dasarnya bisa dilihat dari dua sisi. Pertama, upah minimum merupakan alat proteksi bagi pekerja untuk mempertahankan agar nilai upah yang diterima tidak menurun dalam memenuhi kebutuhan hidup sehari-hari. Kedua, sebagai alat proteksi bagi 
perusahaan untuk mempertahankan produktivitas pekerja (Simanjuntak, dalam Gianie, 2009:1). Beriku beberapa penelitian terdahulu tentang upah, yaitu: Gindling fan Terrell (2006), Rini (2013), Rizal Azaini (2014), dan Wasilaputri (2016). Hasil penelitian menyatakan bahwa upah minimum provinsi berpengaruh negatif terhadap penyerapan tenaga kerja.

Selain upah, ada beberapa faktor yang juga mendapat perhatian dari pemerintah sebagai upaya mengatasi permasalahan ketenagakerjaan yaitu Produk Domestik Regional Bruto (PDRB) dan Investasi. PDRB merupakan nilai tambah atas barang dan jasa yang dihasilkan oleh berbagai unit produksi atau sektor di suatu daerah dalam jangka waktu tertentu. PDRB dapat mempengaruhi jumlah angkatan kerja yang bekerja dengan asumsi apabila nilai PDRB meningkat, maka jumlah nilai tambah output atau penjualan dalam seluruh unit ekonomi disuatu wilayah akan meningkat. Meningkatnya output atau penjualan yang dilakukan perusahaan maka akan mendorong perusahaan untuk menambah permintaan tenaga kerjanya agar produksinya dapat ditingkatkan untuk mengejar peningkatan penjualan yang terjadi (Feriyanto, 2014). Atau dengan kata lain dinyatakan peningkatan PDRB akan meningkatkan permintaan tenaga kerja, ada hubungan positif antara PDRB dengan penyerapan tenaga kerja.

Sektor industri di yakini sebagai sektor yang dapat memimpin sektor-sektor lain dalam sebuah perekonomian menuju kemajuan. Produk-produk industrial selalu memiliki "dasar tukar" (term of trade) yang tinggi atau lebih menguntungkan serta menciptakan nilai tambah yang besar dibanding produk-produk sektor lain. Sejalan dengan hal tersebut, maka peran sektor industri akan semakin penting sehingga dapat dijadikan sebagai prioritas pembangunan yang memiliki peranan sebagai sektor pemimpin bagi pembangunan sektor-sektor lainnya. Salah satu syarat utama bagi pembangunan ekonomi adalah kriteria investasi, dimana tujuan utama dari investasi adalah untuk memperoleh manfaat yang layak di kemudian hari, apabila kegiatan investasi meningkat, maka kegiatan ekonomi pun ikut meningkat. Dengan adanya investasi maka akan meningkatkan produksi dan berdampak pada tingkat penyerapan tenaga kerja.

Investasi merupakan pengeluaran pemerintah dan non pemerintah (swasta), dimana membutuhkan modal riil untuk mendirikan perusahaan baru dengan hasil keutungan mereka dan dapat memperluas usaha yang telah ada. Sehingga dampak positifnya adalah memberikan peningkatan penyerapan tenaga kerja dan peluang kerja bagi masyarakat. Selain itu pula dapat memperoleh keuntungan lebih besar dari modal awal dengan menginvestasikan modalnya tersebut. Investasi khususnya investasi yang berorientasi padat karya sehingga akan memperluas lapangan kerja, dari pada industri padat modal yang hanya menambah modal secara terus menerus tetapi tidak berdampak positif bagi penyerapan tenaga kerja. 


\section{LANDASAN TEORI}

\section{Konsep Tenaga Kerja}

Tenaga kerja merupakan faktor yang terpenting dalam proses produksi. Sebagai sarana produksi, tenaga kerja lebih penting dari pada sarana produksi yang lain seperti bahan mentah, tanah, air, dan sebagainya. Karena manusialah yang menggerakkan semua sumber-sumber tersebut untuk menghasilkan barang.

Menurut Undang-undang No. 13 Tahun 2003 Pasal 1, tenaga kerja adalah tiap orang yang mampu melaksanakan pekerjaan baik di dalam maupun di luar hubungan kerja guna menghasilkan barang dan jasa untuk memenuhi kebutuhan masyarakat. Pada UU No 25 Tahun 1997 mendefinisikan tenaga kerja adalah penduduk usia 15 tahun atau lebih, sedangkan pada undang-undang terbaru tentang ketenagakerjaan yaitu UU No. 13 tahun 2013 tidak memberikan batasan umur dalam definisi tenaga kerja, namun pada undang-undang tersebut melarang mempekerjakan anak - anak. Anak-anak menurut UU No. 25 tahun 1997 tentang ketenagakerjaan adalah orang laki-laki atau wanita yang berumur kurang dari 15 tahun. Berdasarkan UU No. 25 tahun 2007 tentang ketenagakerjaan, ketetapan batas usia kerja penduduk Indonesia adalah 15 tahun.

\section{Penyerapan Tenaga Kerja}

Penyerapan tenaga kerja adalah banyaknya lapangan kerja yang sudah terisi yang tercermin dari banyaknya jumlah penduduk bekerja. Penduduk yang bekerja terserap dan tersebar di berbagai sektor perekonomian. Terserapnya penduduk bekerja disebabkan oleh adanya permintaan akan tenaga kerja. Oleh karena itu, penyerapan tenaga kerja dapat dikatakan sebagai permintaan tenaga kerja (Kuncoro, 2002).

\section{Permintaan Tenaga Kerja dan Pergeserannya}

Menurut teori klasik permintaan tenaga kerja tergantung pada upah, yaitu semakin rendah upah, semakin banyak permintaan tenaga kerja dalam suatu perekonomian. Menurut teori ekonomi Neo Klasik, dalam struktur pasar persaingan diasumsikan bahwa seorang pengusaha tidak dapat mempengaruhi harga (price taker). Untuk memaksimalkan laba, pengusaha hanya dapat mengatur berapa jumlah karyawan yang dipekerjakan. Fungsi permintaan suatu perusahaan akan tenaga kerja didasarkan pada :

- Tambahan hasil marjinal yaitu tambahan hasil (output) yang diproduksi pengusaha dengan menambah seorang pekerja. Tambahan hasil tersebut dinamakan tambahan hasil marjinal atau marjinal physical produk $\left(\mathrm{MPP}_{\mathrm{L}}\right)$ dari tenaga kerja.

- Permintaan marjinal yaitu jumlah uang yang akan diperoleh pengusaha dengan tambahan hasil marjinal tersebut. Jumlah uang ini dinamakan penerimaan marjinal atau marjinal revenue (MR). 
Permintaan marjinal disini merupakan besarnya tambahan hasil marjinal dikalikan dengan harga per unit, sehingga $\mathrm{MR}=\mathrm{VMPP}_{\mathrm{L}}=\mathrm{MPP}_{\mathrm{L}} \times \mathrm{P}$, dan

- Biaya marjinal yaitu jumlah biaya yang dikeluarkan pengusaha dengan mempekerjakan tambahan seorang karyawan, dengan kata lain upah karyawan tersebut. Apabila tambahan penerimaan marjinal lebih tinggi dari biaya marjinal, maka mempekerjakan orang tersebut akan menambahkeuntungan pengusaha, sehingga pengusaha akan terus menambah jumlah karyawan selama MR lebih besar dari tingkat upah (W) (Simanjuntak, 1985).

Banyaknya permintaan output produksi suatu perusahaan dapat menyebabkan naiknya harga output tersebut. Kenaikan harga ini tidak mengubah produk marginal tenaga kerja pada berapaun jumlah tenaga kerja yang dipekerjakan, namun dapat meningkatkan nilai marginal produksinya(Mankiw, 2000).

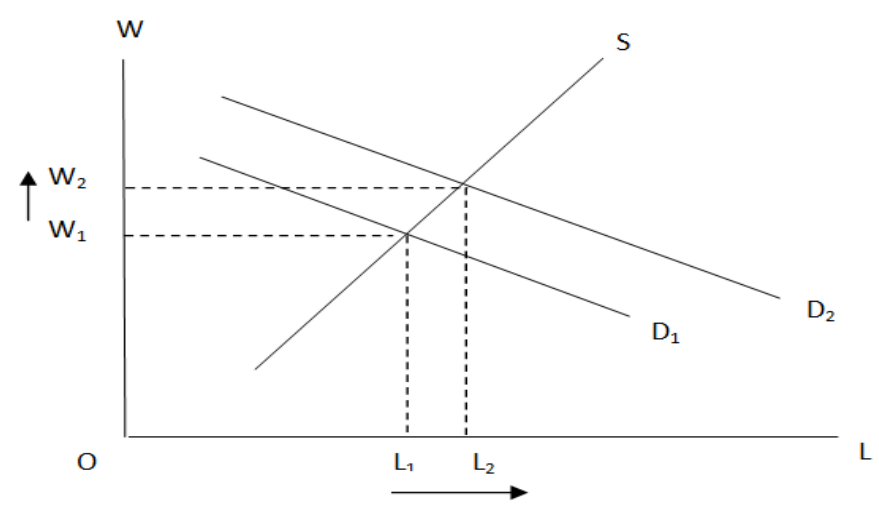

Sumber: Mankiw (2000)

\section{Gambar 2.4 Pergeseran Kurva dalam Permintaan Tenaga Kerja}

Gambar diatas menjelaskan pergeseran permintaan tenaga kerja, ketika permintaan tenaga kerja naik dari $\mathrm{D}_{1}$ ke $\mathrm{D}_{2}$ dikarenakan naiknya harga output, keseimbangan upah naik dari $\mathrm{W}_{1} \mathrm{ke} \mathrm{W}_{2}$ dan jumlah tenaga kerja juga ikut naik dari $\mathrm{L}_{1}$ ke $\mathrm{L}_{2}$.

\section{Pengukuran Permintaan Tenaga Kerja}

Cara pertama biasa dilakukan bila input faktor produksi yang diminta suatu industri tersedia dengan lengkap, sementara cara ke dua bisa dilakukan bila input produksi terbatas jumlahnya. Menggunakan teknik Langrange Multipilier $(\lambda)$, derivasi permintaan industri terhadap tenaga kerja ini dapat dilakukan dengan menggunakan fungsi produksi yang sudah dikenal, seperti fungsi CobbDouglas, fungsi produksi CES atau Fungsi Translog.

Menggunakan cara ke dua, derivasi permintaan terhadap tenaga kerja suatu industri dengan menggunakan fungsi Cobb-Douglas sebagai berikut:

$\begin{array}{ll}\text { Minimum ongkos } & \mathrm{C}=\mathrm{w}_{\mathrm{k}} \cdot \mathrm{K}+\mathrm{w}_{\mathrm{L}} \cdot \mathrm{L} \\ \text { Dengan kendala } & \mathrm{Q}=\mathrm{AK}^{\alpha} \mathrm{L}^{\beta}\end{array}$ 
Yang mana

$\mathrm{C}=$ Total ongkos

Wk = Tingkat bunga/harga barang modal

$\mathrm{K} \quad=$ Modal

$\mathrm{WL}=$ Upah Pekerja

$\mathrm{L} \quad=$ Pekerja

$\mathrm{Q} \quad=$ Output

A $\quad=$ Teknologi

Turunan pertama (First Order condition) dari persamaaan yang telah mengimpose kendala produksi dapat diperhatikan di bawah ini :

$\xi=w k \cdot K+w_{1} L+\lambda\left(Q-A K^{\alpha} L^{\beta}\right)$

$\delta \xi / \delta \mathrm{L}=w \mathrm{w}-\lambda \alpha \mathrm{AK}^{\alpha-1} \mathrm{~L}^{\beta}=0$

$\delta \xi / \delta \mathrm{K}=w 1-\lambda \beta \mathrm{AK}^{\alpha} \mathrm{L}^{\beta-1}=0$

$\delta \xi / \delta \lambda=\mathrm{Q}-\mathrm{AK}^{\alpha} \mathrm{L}^{\beta} \quad=0$

Penyelesaian persamaan (4) dan (5) dengan memperlihatkan syarat keseimbangan penggunaaan input dengan keuntungan maskimum diperoleh hasil sebagai berikut:

$\frac{W_{l}}{W_{k}}=\frac{\alpha K}{\beta L}$

Penyederhanaan persamaan (4) dan (5) akan menghasilkan permintaan industri masingmasing input sebagai berikut:

$$
\begin{aligned}
& K=\left[\frac{Q}{A L^{\beta}}\right]^{\frac{1}{\alpha}} \\
& L=\left[\frac{\propto W k}{\beta W l}\right] K
\end{aligned}
$$

Proses derivasi permintaan tenaga kerja industri diatas dilanjutkan dengan penerapan langkah-langkah mengimpose persamaaan (8) ke persamaan (9), sehingga diperoleh persamaan baru:

$L=\left[\frac{\alpha W k}{\beta W l}\right]^{\alpha}\left[\frac{Q}{A}\right]^{\frac{1}{\alpha+\beta}}$

$L=\frac{\alpha W_{k}}{\beta W_{l}}\left[\frac{Q^{1 / \alpha}}{A^{1 / \alpha} L^{\beta / \alpha}}\right]$

L. $L^{\frac{\beta}{\alpha}}=\frac{\alpha W_{k}}{\beta W_{l}}\left[\frac{Q^{1 / \alpha}}{A^{1 / \alpha}}\right]$

$L^{1+\frac{\beta}{\alpha}}=\frac{\alpha W_{k}}{\beta W_{l}}\left[\frac{Q^{1 / \alpha}}{A^{1 / \alpha}}\right]$

$L^{\alpha+\frac{\beta}{\alpha}}=\frac{\alpha W_{k}}{\beta W_{l}}\left[\frac{Q^{1 / \alpha}}{A^{1 / \alpha}}\right]$

$L^{*}=\left[\frac{\alpha W_{k}}{\beta W_{l}}\right]^{\alpha} \quad\left[\frac{Q}{A}\right]^{1 / \alpha+\beta}$ 
Dari persamaan di atas selanjutnya dilakukan transformasi persamaan ke dalam bentuk logaritma, maka fungsi linier permintaan industri terhadap tenaga kerja dapat ditulis kembali menjadi:

$$
\mathrm{InL}=\ln \mathrm{A}+\alpha_{1} \ln \mathrm{Wk}+\alpha_{2} \ln \mathrm{W}_{1}+\alpha_{3} \ln \mathrm{Q}+\varepsilon
$$

Yang mana :

$\operatorname{lnL} \quad=\log$ permintaan tenaga kerja industri

$\operatorname{lnWk}=\log$ harga barang - barang modal

$\mathrm{InW}_{1} \quad=\log$ upah pekerja

InQ $\quad=\log$ output

$\alpha_{1,2,3}=$ elastisitas harga barang modal, harga upah pekerja dan elastisitas permintaan output

A $\quad=$ Indeks efisiensi masukan atau merupakan juga indeks teknologi

$\mathrm{E} \quad=$ error term

Persamaan (16) memperlihatkan bahwa permintaan tenaga kerja industri sangat ditentukan oleh harga input itu sendiri, harga modal (barang lain) dan tingkat output di masing-masing industri. Fungsi permintaan ini dapat diestimasi untuk permintaan tenaga kerja menurut sektor dan jenis pekerjaan. Seberapa besar dampak pertambahan produksi membuka lapangan kerja dapat diperoleh dengan memperlihatkan nilai koefisien variabel output (Budiarty, 2006).

Dari persamaan diatas dapat dijelaskan bahwa Wk (harga modal) dapat digantikan atau diproxykan sebagai investasi, $\mathrm{W}_{\mathrm{L}}$ (upah pekerja) sebagai Upah Minimum Provinsi (UMP), dan $\mathrm{Q}$ (output) sebagai Produk Domestik Regional Bruto (PDRB). Investasimerupakan proxy dari Wk (harga modal), Investasi ini merupakan bagian dari kapital stok (harga modal), karena $K t_{+1}=K t+(1-$ d) It dimana (kapital stok tahun $\mathrm{t}_{+1}$ itu adalah kapital stok tahun $\mathrm{ini}+1$ - depresesion $\mathrm{x}$ investasi ). Jika ada investasi maka kapital naik, sehingga gerakan investasi dan kapital searah. Investasi ada, maka kapital stok tahun depan pasti bertambah secara akumulasi. Sehingga investasi dapat digunakan untuk mempresentasikan kapital stok. Karena pertambahan kapital stok tahun depan berasal dari investasi.

Menurut Khalid Javedet.al (2001) dalam Rosalina (2013) dengan asumsi bahwa hubungan positif antara investasi dengan penyerapan tenaga kerja beralasan karena investasi mengacu pada pengeluaran untuk perluasan usaha dan peralatan baru. Perluasan usaha dan peralatan baru dikelola dan digerakkan oleh tenaga kerja manusia, sehingga peningkatan investasi mampu meningkatkan penyerapan tenaga kerja.

Upah Minimum Provinsi (UMP) dapat merupakan proxy dari $\mathrm{W}_{\mathrm{L}}$ (upah pekerja) karena upah minimum merupakan upah standar terendah yang harus digunakan oleh para pengusaha atau pelaku industri untuk memberikan upah kepada pekerja di dalam lingkungan usaha disebuah wilayah. Sekalipun terdapat beberapa ketentuan upah minimum, namun upah minimum yang berlaku bagi setiap buruh/pekerja dalam suatu wilayah pada suatu industri tertentu hanya satu jenis upah minimum. 
Mengingat tidak tersedianya data upah minimum atau data upah sektoral di wilayah penelitian, maka digunakan Upah Minimum Provinsi sebagai proksi dari upah yang berlaku dan Upah Minimum Sektoral di Provinsi tertentu.

Pengusaha dilarang membayar upah lebih rendah dari upah minimum. Upah memiliki hubungan negatif terhadap penyerapan tenaga kerja. Hal ini disebabkan upah dipandang sebagai beban bagi perusahaan, karena upah merupakan biaya yang harus dikeluarkan untuk pembiayaan tenaga kerja (input produksi). Semakin besar tingkat upah akan semakin kecil keuntungan yang akan diperoleh perusahaan, dengan kenaikan upah maka perusahaan akan menurunkan jumlah tenaga kerja. Menurut Todaro (2006), perusahaan akan terus menambah tenaga kerja selama penerimaan tambahan (hasil kali jumlah output tambahan yang diperoleh perusahaan dari satu unit tenaga kerja tambahan dengan mempertahankan jumlah modal tetap, P x MPLL) melebihi upah.

Di samping Investasi dan UMP, PDRB juga merupakan proxy dari Q (output) menurut Dimas dan Woyanti (2009), sesua teori produksi yang menyatakan bahwa permintaan input merupakan derived demand dari permintaan output yang artinya permintaan akan input (tenaga kerja) barut terjadi bila ada permintaan akan output. Permintaan barang dan jasa inilah yang akan melatar belakangi perusahaan atau industri untuk berproduksi, dan nantinya akan mampu menyerap tenaga kerja.

\section{Mekanisme Penetapan Upah Minimum}

Menurut Kaufman (2000), tujuan utama ditetapkannya upah minimum adalah memenuhi standar hidup minimum seperti untuk kesehatan, efisiensi, dan kesejahteraan pekerja. Gambar 2.5 menjelaskan peraturan upah minimum yang dikenakan pada pasar tenaga kerja yang bersifat persaingan sempurna. Tingkat upah minimum yang berlaku sebelum ada peraturan upah minimum adalah $\mathrm{W}_{1}$ dan jumlah orang yang dipekerjakan adalah $0 \mathrm{X}_{1}$ (yaitu, keseimbangan terjadi pada $\mathrm{E}$ ). Dengan dikenakannya peraturan upah minimum maka tingkat upah tidak bisa turun dibawah $\mathrm{W}$ dan ini mengakibatkan permintaan akan tenaga kerja turun menjadi $0 \mathrm{X}_{2}$ sedang jumlah tenaga kerja yang menawarkan diri adalah $0 \mathrm{X}_{3}$. Ini berarti bahwa tingkat upah yang lebih tinggi tersebut harus dibayar dengan ongkos sosial berupa $X_{2} X_{1}$ orang yang semula bekerja sekarang kehilangan pekerjaan dan $X_{1} X_{3}$ orang baru yang mencari pekerjaan. Jadi jumlah pengangguran total adalah $X_{2} X_{3}$ orang $=\left(X_{2} X_{1}\right.$ $+\mathrm{X}_{1} \mathrm{X}_{3}$ ) orang(Boediono, 2003). 




Sumber: Boediono, 200.

Gambar 2.5 Penetapan Upah Minimum di Pasar Tenaga Kerja

\section{Perkembangan Teori Upah}

Upah dan pembentukan harga upah tenaga kerja akan dikemukakan beberapa teori yang menerangkan tentang latar belakang terbentuknya harga upah tenaga kerja.

\section{- Teori Penyamaan Tingkat Upah}

Disadari atau tidak tingkat kepuasan (atau tingkat ketidakpuasan) masing-masing pekerja atas suatu pekerjaan tidaklah sama, maka bisa dipahami terjadinya kemungkinan perbedaan tingkat upah yang mencerminkan adanya perbedaan selera atau preferensi terhadap setiap jenis pekerjaan.

\section{- Teori Upah Ricardo}

Tingkat upah sebagai balas jasa bagi tenaga kerja merupakan harga yang diperlukan untuk mempertahankan dan melanjutkan kehidupan tenaga kerja. Ricardo juga menyatakan bahwa perbaikan upah hanya ditentukan oleh perbuatan dan perilaku tenaga kerja sendiri dan pembentukan upah sebaiknya diserahkan kepada persaingan bebas di pasar. Teori ini menerangkan:

1) Upah menurut kodrat upah adalah yang cukup untuk pemeliharaan hidup pekerja dengan keluarganya.

2) Di pasar akan terdapat upah menurut harga pasar adalah upah yang terjadi di pasar dan ditentukan oleh permintaan dan penawaran. Upah harga pasar akan berubah disekitar upah menurut kodrat. Oleh para ahli ekonomi modern, upah kodrat dijadikan batas minimum dari upah kerja.

\section{- Teori Upah Besi}


Hukum Upah Besi adalah hukum yang diusulkan ekonomi yang menyatakan bahwa upah riil selalu cenderung, dalam jangka panjang, terhadap upah minimum yang diperlukan untuk menyokong kehidupan pekerja. Teori ini pertama kali disebut oleh Ferdinand Lassalle (1999) pada pertengahan abad kesembilan belas.

\section{- Teori Upah Malthus}

Malthus merupakan salah satu seorang tokoh klasik yang meninjau upah dalam kaitannya dengan perubahan penduduk. Menurut Malthus, jumlah penduduk merupakan faktor strategis yang dipakai untuk menjelaskan berbagai hal. Malthus menyatakan bila penduduk bertambah, penawaran tenaga kerja juga bertambah sehingga dapat menekan tingkat upah. Demikian juga sebaliknya, tingkat upah akan meningkat jika penawaran tenaga kerja berkurang akibat jumlah penduduk yang menurun.

\section{Produk Domestik Regional Bruto (PDRB)}

Produk Domestik Regional Bruto (PDRB) sebagai salah satu indikator ekonomi memuat berbagai instrumen ekonomi yang di dalamnya terlihat jelas keadaan makro ekonomi suatu daerah dengan pertumbuhan ekonominya, pendapatan perkapita dan berbagai instrumen ekonomi lainnya. PDRB dapat didefinisikan berdasarkan tiga pendekatan yaitu :

- Pendekatan Produksi

- Pendekatan Pendapatan

- Pendekatan Pengeluaran

Produk domestik daerah merupakan semua barang dan jasa yang dihasilkan dari kegiatankegiatan ekonomi yang berlangsung di wilayah domestik, tanpa memperdulikan asal dan kepemilikan faktor produksi dari penduduk daerah tersebut ataupun tidak. Penghitungan produk domestik lebih dikenal dengan istilah Produk Domestik Regional Bruto (PDRB), disebut domestik karena menyangkut batas wilayah dan dinamakan bruto karena telah memasukkan komponen penyusutan dalam perhitungannya.

Mankiw (2006:248) menjelaskan, hukum okun adalah relasi negatif antara pengangguran dan GDP. Hukum okun merupakan pengingat bahwa faktor-faktor yang menentukan siklus bisnis pada jangka pendek sangat berbeda dengan faktor-faktoryang membentuk pertumbuhan ekonomi jangka panjang. Hukum Okun (Okun's law) merupakan hubungan negatif antara pengangguran dan GDP Riil,yang mengacu pada penurunan dalam pengangguran sebesar 1 persen dikaitkan dengan pertumbuhan tambahan dalam GDP Riil yang mendekati 2 persen. Dengan kata lain, PDRB yang pada akhirnya mempengaruhi GDP berpengaruh positif terhadap penyerapan tenaga kerja. Peningkatan jumlah PDRB akan berpengaruh pada peningkatan penyerapan tenaga kerja, begitu juga sebaliknya penurunan jumlah PDRB akan berpengaruh pada penurunan penyerapan tenaga kerja.

Hal tersebut didukung oleh hasil penelitian yang dilakukan oleh Dimas dan Nenik (2009) yang menyatakan bahwa PDRB memiliki pengaruh yang positif dan signifikan terhadap penyerapan 
tenaga kerja di DKI Jakarta, dimana apabila PDRB meningkat satu persen maka penyerapan tenaga kerja meningkat sebesar1,23 persen. Rakhmasari (2006) juga mengatakan bahwa faktor-faktor yang mempengaruh penyerapan tenaga kerja salah satunya adalah PDRB dan memiliki hubungan positif yang selanjutnya diperkuat oleh hasil penelitian Ferdinan (2011) yang mengatakan bahwa besarnya PDRB merupakan faktor signifikan yangmempengaruhi penyerapan tenaga kerja di Provinsi Sumatera Barat yang jugamemiliki pengaruh positif.

Kesimpulannya, dari teori dan hasil penelitian-penelitian yang terdahulu PDRB memiliki pengaruh yang positif terhadap penyerapan tenaga kerja. Apabila jumlah PDRB meningkat maka jumlah penyerapan tenaga kerja juga akan meningkat, begitu juga sebaliknya.

\section{Investasi}

Investasi merupakan komponen utama dalam menggerakan roda perekonomian suatu negara. Secara teori peningkatan investasi akan mendorong volume perdagangan dan volume produksi yang selanjutnya akan memperluas kesempatan kerja yang produktif dan berarti akan meningkatkan pendapatan perkapita sekaligus bisa meningkatkan kesejahteraan masyarakat.

\section{METODE PENELITIAN}

\section{Jenis dan Sumber Data}

Penelitian ini menggunakan pendekatan deskriptif kuantitatif dan analisis data panel. Data yang digunakan adalah data panel enam Provinsi di Pulau Jawa Tahun 2010-2016. Data akan diolah menggunakan teknik data panel yang merupakan kombinasi dari data time series dan cross section. Data ini bersumber dari Badan Pusat Statistik (BPS) Pulau Jawa Dalam Angka. Adapun data yang diperlukan dalam penelitian ini adalah data Upah Minimum Provinsi (UMP), data Produk Domestik Regional Bruto (PDRB), dan Investasi. Data tersebut adalah investasi yang berasal dari Penanaman Modal Dalam Negeri (PMDN) dan Penanaman Modal Asing (PMA).

\section{Metode Analisis Data}

Analisis data yang digunakan dalam penelitian ini adalah estimasi data panel. Data panel yaitu model ekonometri yang menyatukan antara deret waktu (time series) dan data kerat lintang (cross section), model ini ditransformasi ke dalam bentuk model logaritma (Log), sebagai berikut:

\section{$\operatorname{LogPTKI} I_{i t}=\log \beta_{0}+\beta_{1} \log U M P_{i t}+\beta_{2} \operatorname{LogPDRB} B_{i t}+\beta_{3} \log I_{i t}+e_{i t}$}

Keterangan :

$\log \quad=$ Logaritma

PTKI = Penyerapan tenaga kerja industry (jiwa) 


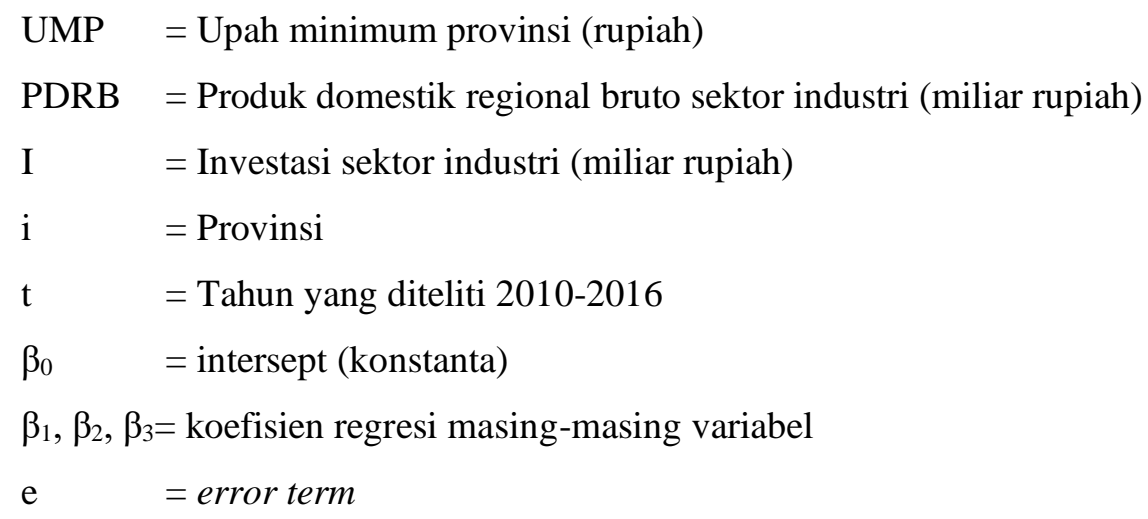

\section{Metode Estimasi Data Panel}

Data panel menurut Gujarati (2003) merupakan suatu data cross section (individu/sektor) yang disusun berdasarkan runtun waktu (time series). Terdapat tiga pendekatan dalam perhitungan model data panel, yaitu: Common Effect (PLS), Fixed Effect (FEM), dan Random Effect (REM). Tentu dalam pengujian diharuskan memilih permodelan yang terbaik. Maka terdapat dua cara pengujian yang umum digunakan yaitu uji Chow (pengujian yang dilakukan untuk memilih model pendekatan yang paling baik antara Common Effect dan Fixed Effect) dan uji Hausman (pengujian ini untuk memilih model terbaik anatara Fixed Effect atau Random Effect), serta Uji Breusch-Pagan (pengujian ini untuk memilih model terbaik anatara Common Effect atau Random Effect).

\section{Metode Pemilihan Model (Uji Kesesuaian Model)}

\section{Uji Chow}

Pengujian yang dilakukan untuk memilih apakah model akan dianalisis menggunakan common effect model (CEM) atau fixed effect model (FEM) dapat dilakukan dengan Uji Chow.

\section{Uji Hausman}

Pengujian untuk memilih apakah model akan dianalisis menggunakan random effect model (REM) atau fixed effect model (FEM) dapat dilakukan dengan uji hausman.

\section{Uji Langrange Multiple (LM)}

Pengujian untuk memilih apakah model akan dianalisis menggunakan metode random effect atau common effect. Uji Langrange Multiple (LM) didasarkan pada distribusi Chi-Squares dengan derajat kebebasan (df) sebesar jumlah variabel independen.

\section{- Uji Asumsi Klasik}

\section{Uji Normalitas}

Pengujian normalitas data adalah pengujian tentang kenormalan distribusi residual data. Pengujian normalitas dilakukan dengan maksud untuk melihat normal tidaknya residual yang dianalisis. Selain menggunakan grafik, uji normalitas juga dapat dilakukan dengan metode JarqueBerra (uji $J B$ ) atau dengan melihat plot dari sisaan. Keputusan terdistribusi normal tidaknya residual 
secara sederhana dengan membandingkan nilai Probabilitas JB (Jarque-Bera) hitung dengan tingkat alpha 0,05 (5\%). Apabila Prob. JB hitung $>\alpha 0,05$ maka dapat disimpulkan bahwa residual terdistribusi normal. Sebaliknya jika Prob. JB hitung $<\alpha 0,05$ maka tidak cukup bukti untuk menyatakan bahwa residual terdistribusi normal.

\section{Multikolinieritas}

Salah satu cara untuk mendeteksi adanya multikolinearitas dengan melihat nilai koefisien korelasi antara peubah bebas dalam model. Jika nilai masing-masing koefisien korelasinya lebih besar dari rule of thumb (0.8) maka model tersebut mengandung multikolinearitas.

\section{Heteroskesdastisitas}

Uji ini bertujuan untuk menguji apakah dalam sebuah model regresi terjadi ketidaknyamanan varian dari residual satu pengamatan ke pengamatan lain. Jika varian berbeda, disebut heteroskedastisitas. Salah satu cara untuk mengetahui ada tidaknya heteroskedastisitas dalam suatu model regresi linier berganda adalah dengan melihat grafik sccatterplot atau nilai prediksi variabel terikat yaitu SRESID dengan residual error yaitu ZPRED. Jika tidak ada pola tertentu dan tidak menyebar diatas dan dibawah angka nol pada sumbu y, maka tidak terjadi heteroskedastisitas. Model yang baik adalah yang tidak terjadi heteroskedastisitas (Ghozali, 2016;134).

\section{Autokorelasi}

Menurut Ghozali (2016;107) autokorelasi muncul karena observasi yang berurutan sepanjang waktu berkaitan satu sama lainnya. Permasalahan ini muncul karena residual tidak bebas dari satu observasi ke observasi lainnya. Model regresi yang baik adalah model regresi yang bebas dari autokolerasi. Cara untuk mendeteksi ada tidaknya autokorelasi adalah dengan uji Run Test. Run test merupakan bagian dari statistik non-parametik dapat pula digunakan untuk menguji apakah antar residual terdapat korelasi yang tinggi. Jika antar residual tidak terdapat hubungan korelasi maka dikatakan bahwa residual adalah acak atau random. Run test digunakan untuk melihat apakah data residual terjadi secara random atau tidak (sistematis).

\section{Uji Hipotesis}

\section{Uji t-statistik}

Uji t-statistik digunakan untuk mengetahui pengaruh variabel independen secara parsial terhadap variabel dependen. Uji $\mathrm{t}$ dapat dilakukan dengan membandingkan nilai probability $\alpha=$ $0,05 \%$ dengan taraf signifikansinya.

\section{Uji F Statistik}

Untuk menunjukkan apakah keseluruhan variabel bebas berpengaruh terhadap variabel terikat pada tingkat $\alpha=0,05 \%$.

\section{Uji Koefisien Determinasi $\left(R^{2}\right)$}


Koefisien Determinasi $\left(\mathrm{R}^{2}\right)$ mengukur seberapa besar variabel independen dalam model dapat menjelaskan variabel dependen yang digunakan dalam penelitian.

\section{HASIL DAN PEMBAHASAN}

\section{- Pengujian Model Data}

\section{Uji Chow}

Menurut Widarjono (2013), Uji Chow merupakan pengujian yang dilakukan untuk memilih model pendekatan yang paling baik antara Common Effect(CE) dan Fixed Effect(FE) dengan melihat nilai distribusi F statistik.

\section{Tabel 1. Uji Chow}

\begin{tabular}{lccc}
\hline Redundant Fixed Effects Tests & & & \\
Equation: EQ01 \\
Test cross-section fixed effects & & & \\
\hline Effects Test & Statistic & d.f. & Prob. \\
\hline Cross-section F & 2260.678444 & $(5.33)$ & 0.0000 \\
\hline
\end{tabular}

Sumber: Output Eviews 8

Tabel 1 menunjukkan bahwa nilai Prob. Cross-section F sebesar 0,0000 lebih kecil dari taraf nyata $(\alpha) 5 \%,(0,0000<0,05)$ maka Ho tidak dapat diterima atau berarti metode Fixed Effect Model (FEM) lebih baik dari pada metode Common Effect Model (CEM) dalam menganalisis data panel di penelitian ini.

\section{Uji Hausman}

Uji Hausman merupakan pengujian yang dilakukan untuk membandingkan dan memilih antara Random Effect Model (REM) dan Fixed Effect Model (FEM).

Tabel 2. Hasil Uji Hausman

\begin{tabular}{|c|c|c|c|}
\hline $\begin{array}{l}\text { Correlated Random Ef } \\
\text { Equation: EQ01 } \\
\text { Test cross-section rand }\end{array}$ & sman Test & & \\
\hline $\begin{array}{l}\text { Test Summary } \\
\text { Prob. }\end{array}$ & Chi-Sq. Statistic & Chi-Sq. & d.f. \\
\hline Cross-section random & 14.733620 & 3 & 0.0021 \\
\hline
\end{tabular}

Sumber: Output Eviews 8

Berdasarkan Tabel 2 diperoleh nilai Chi-Squares Statistic sebesar 14,733620 yang lebih besar dari nilai Chi-Squares tabel sebesar 7,81, maka $\mathrm{H}_{0}$ tidak dapat diterima atau berarti metode Fixed 
Effect (FEM) lebih baik dari pada metode Random Effect (REM) dalam menganalisis data panel di penelitian ini.

\section{Uji Breusch-Pagan LM}

Uji Breusch-Pagan Lagrange Multiplier (LM) dilakukan untuk memilih metode terbaik antara Common Effect Model (CEM) dengan Random Effect Model (REM).

Tabel 3. Hasil Uji Breusch-Pagan Lagrange Multiplier (LM)

\begin{tabular}{lccc}
\hline $\begin{array}{l}\text { Null (no rand. Effect) } \\
\text { Alternative }\end{array}$ & $\begin{array}{c}\text { Cross-section } \\
\text { One-sided }\end{array}$ & $\begin{array}{c}\text { Period } \\
\text { One-sided }\end{array}$ & Both \\
\hline Breusch-Pagan & 39.323363 & 0.327176 & 39.65053 \\
& $(0.0000)$ & $(0.5673)$ & $(0.0000)$ \\
\hline
\end{tabular}

Sumber: Output Eviews 8

Berdasarkan Tabel 3 diperoleh nilai Cross-section Breusch-Pagan adalah sebesar 39,32336 yang lebih besar dari nilai kritis Chi-Squares tabel sebesar 7,81, maka $\mathrm{H}_{0}$ tidak dapat diterima artinya metode Random Effect Model (REM) lebih baik dari pada metode Common Effect Model (CEM) untuk menganalisis data panel penelitian maka disimpulkan analisis diperlukan selanjutnya akan menggunakan model Random Effect (RE).

\section{- Hasil Regresi Fixed Effect Model}

$$
\begin{array}{cccc}
\operatorname{LogPTKI} & =8,399585-0,874935 \log \mathrm{UMP}_{\mathrm{it}}+ & 0,561902 \log \mathrm{PDRB}_{\mathrm{it}} & +0,821413 \log _{\mathrm{it}} \\
\text { s.e } & (0.030143) & (0.003497) & (0.003243)
\end{array}
$$

Keterangan : $\left.{ }^{* *}\right) \alpha=$ signifikan pada level 5\%

Berdasarkan hasil estimasi tersebut menunjukkan bahwa angka koefisien regresi variabel UMP adalah sebesar -0,874935. Hal ini menunjukkan bahwa terdapat pengaruh negatif $(\alpha=0,05)$ dari variabel UMP terhadap penyerapan tenaga kerja sektor industri di Pulau Jawa tahun 2010-2016. Setiap kenaikan UMP sebesar 1\%, akan cenderung menurunkan penyerapan tenaga kerja sektor industri di Pulau Jawa sebesar $0,87 \%$. Hasil penelitian yang telah dilakukan mendukung temuan dari Wasilaputri (2016) dalam penelitiannya menemukan bahwa tingkat upah memiliki pengaruh terhadap penyerapan tenaga kerja, dimana setiap kenaikan $1 \%$ upah minimum provinsi akan diikuti oleh penurunan penyerapan tenaga kerja sebesar $0,12 \%$, ceteris paribus.

Selanjutnya koefisien regresi variabel PDRB adalah sebesar 0,561902. Hal ini menunjukkan bahwa terdapat pengaruh positif $(\alpha=0,05)$ dari variabel PDRB terhadap penyerapan tenaga kerja sektor industri di Pulau Jawa tahun 2010-2016. Setiap kenaikan 1\% PDRB akan cenderung diikuti 
oleh kenaikan penyerapan tenaga kerja sebesar $0,56 \%$, ceteris paribus. Hal tersebut didukung oleh hasil penelitian yang dilakukan oleh Dimas dan Nenik (2009) yang menyatakan bahwa PDRB memiliki pengaruh yang positif terhadap penyerapan tenaga kerja di DKI Jakarta, apabila PDRB meningkat $1 \%$ maka penyerapan tenaga kerja meningkat sebesar $1,23 \%$.

Sedangkan koefisien regresi variabel investasi adalah sebesar 0,821413. Hal ini menunjukkan bahwa investasi berperngaruh positif $(\alpha=0,05)$ terhadap penyerapan tenaga kerja sektor industri di Pulau Jawa tahun 2012-2016. Setiap kenaikan investasi sebesar 1\%, akan cenderung menurunkan penyerapan tenaga kerja sektor industri di Pulau Jawa sebesar $0,82 \%$. Hal ini didukung oleh penelitian yang dilakukan Roni (2010), bahwa investasi berpengaruh positif dan signifikan terhadap penyerapan tenaga kerja di Indonesia. Ketika terjadi kenaikan investasi sebesar 1\% maka akan meningkatkan penyerapan tenaga kerja sebesar $0,01 \%$.

Tabel 4. Nilai Prediksi

\begin{tabular}{|c|c|c|c|c|c|c|c|}
\hline \multirow{2}{*}{ Provinsi } & \multicolumn{3}{|c|}{ Koefisien } & \multirow{2}{*}{ RATA -RATA PTKI } & \multicolumn{3}{|c|}{ Nilai Prediksi PTKI * $(\%)$} \\
\hline & $\mathrm{UMP}(\%)$ & PDRB $(\%)$ & $\mathrm{I}(\%)$ & & UMP & PDRB & $\mathrm{I}$ \\
\hline DKI Jakarta & $-0,87$ & 0,56 & 0,82 & 549.115 & $-4,777$ & 3,075 & 4,503 \\
\hline Jawa Barat & $-0,87$ & 0,56 & 0,82 & 3.490 .401 & $-30,366$ & 19,546 & 28,621 \\
\hline Jawa Tengah & $-0,87$ & 0,56 & 0,82 & 3.098 .789 & $-26,959$ & 17,353 & 25,410 \\
\hline DI Yogyakarta & $-0,87$ & 0,56 & 0,82 & 486.226 & $-4,230$ & 2,723 & 3,987 \\
\hline Jawa Tengah & $-0,87$ & 0,56 & 0,82 & 2.653 .167 & $-23,083$ & 14,858 & 21,756 \\
\hline Banten & $-0,87$ & 0,56 & 0,82 & 1.154 .834 & $-10,047$ & 6,467 & 9,470 \\
\hline
\end{tabular}

Sumber: Excel, data diolah

Keterangan : * Proyeksi UMP, PDRB, dan I apabila terjadi kenaikan sebesar $1 \%$ terhadap penyerapan tenaga kerja.

Dari Tabel 4 dapat dilihat bahwa sumber pengaruh terbesar dari peningkatan tenaga kerja dapat dilihat dari Investasi yang berada di Provinsi Jawa Barat yaitu sebesar 28,621\%. Sedangkan sumber terendah dari peningkatan tenaga kerja berada di Provinsi Jawa Barat berupa UMP sebesar $30,366 \%$.

\section{Hasil Uji Asumsi Klasik}

\section{Uji Normalitas}

Berdasarkan hasil regresi, diketahui bahwa nilai probability sebesar 0,673936. Nilai probability 0,637634 > 0,05 maka data berdistribusi normal. Sehingga dapat disimpulkan bahwa asumsi berdistribusi normal dalam model terpenuhi.

\section{Uji Autokorelasi}

Tabel 5. Hasil Uji Autokorelasi

R-squared $\quad 0.999816 \quad$ Mean dependent var 8869.964




$\begin{array}{llll}\text { Adjusted R-squared } & 0.999772 & \text { S.D. dependent var } & 19852.85 \\ \text { S.E. of regression } & 1.090111 & \text { Sum squared resid } & 39.21527 \\ \text { F-statistic } & 22439.14 & \text { Durbin-Watson stat } & 1.910139 \\ \text { Prob(F-statistic) } & 0.000000 & \text { Mean dependent var } & \end{array}$

Sumber: Output Eviews 8

Berdasarkan Tabel 5 di atas diketahui bahwa nilai Durbin Watson sebesar 1,910139. Karena nilai du $(1,67)<\mathrm{d}(1,910139)<4$ - du $(2,33)$ maka model regresi tidak mengandung autokorelasi atau asumsi tidak terjadi autokorelasi terpenuhi.

\section{Uji Multikolinieritas}

Tabel 6. Hasil Uji Multikolinieritas

\begin{tabular}{cccc}
\hline & LOG(UMP) & LOG(PDRB) & LOG(I) \\
\hline LOG(UMP) & 1.000000 & 0.146122 & 0.359374 \\
LOG(PDRB) & 0.146122 & 1.000000 & 0.395702 \\
LOG(I) & 0.359374 & 0.395702 & 1.000000 \\
\hline Sumber: Output Eviews 8 & &
\end{tabular}

Dari Tabel 6 diketahui bahwa nilai korelasi antar variabel bebas lebih kecil dari 0,8 $(r<0,8)$ yang berarti model tidak mengandung masalah multikolinieritas atau asumsi tidak terjadi multikolinieritas dalam model terpenuhi.

\section{Uji Heteroskedastisitas}

Tabel 7. Hasil Uji Heteroskedastisitas

\begin{tabular}{lcccc}
\hline \multicolumn{1}{c}{ Variabel } & Coefficient & Std. Error & t-Statistic & Prob. \\
\hline C & 7.316670 & 5.162388 & 1.417303 & 0.1658 \\
LOG(UMP) & -1.557550 & 2.223159 & -0.700602 & 0.4885 \\
LOG(PDRB) & -0.583479 & 0.421714 & -1.383588 & 0.1758 \\
LOG(I) & 1.576293 & 1.841920 & 0.855788 & 0.3983 \\
\hline Sumber: Output Eviews 8 & & &
\end{tabular}

Berdasarkan Tabel 7 nilai probabilitas dari masing-masing variabel bebas tidak ada yang signifikan ( $p$-value > 0.05). Hal ini menunjukkan bahwa model bersifat homoskedastis atau asumsi tidak mengandung heteroskedastis terpenuhi.

\section{Uji Hipotesis}

\section{Uji t-statistik (Keberartian Parsial)}

Tabel 8. Hasil Uji t-statistik

\begin{tabular}{lccccl}
\hline Variabel & Koefisien & t-statistik & t-tabel & Prob. & Kesimpulan \\
\hline UMP & -0.874935 & -250.1811 & -1.68595 & 0.0000 & TolakH $_{o}$ \\
PDRB & 0.561902 & 173.2863 & 1.68595 & 0.0000 & ${\text { Tolak } H_{o}}$
\end{tabular}




\section{Investasi $\quad 0.821413 \quad 261.7905 \quad 1.68595 \quad 0.0000 \quad$ Tolak $\mathrm{H}_{\mathrm{o}}$}

\section{Sumber: Output Eviews 8}

Berdasarkan Tabel 8 menunjukkan nilai t-statistik variabel sebesar -250,1881 sedangkan nilai t-tabel sebesar -1,68595. Hal ini menunjukkan bahwa nilai t-statistik lebih besar daripada nilai t-tabel. Dengan demikian H0 ditolak dan Ha diterima, artinya variabel UMP berpengaruh negatif dan signifikan terhadap penyerapan tenaga kerja. Variabel PDRB menunjukkan nilai t-statistik sebesar 173,2863 sedangkan nilai t-tabel sebesar 1,68595. Hal ini menunjukkan bahwa nilai t-statistik lebih besar daripada nilai t-tabel. Dengan demikian H0 ditolak dan Ha diterima, artinya variabel PDRB berpengaruh positif dan signifikan terhadap penyerapan tenaga kerja di Pulau Jawa. Variabel Investasi menunjukkan nilai t-statistik variabel sebesar 261,7905 sedangkan nilai t-tabel sebesar 1,68595. Hal ini menunjukkan bahwa nilai t-statistik lebih besar daripada nilai t-tabel. Dengan demikian H0 ditolak dan Ha diterima, artinya variabel PDRBberpengaruh positifdan signifikan terhadap penyerapan tenaga kerja di Pulau Jawa.

\section{Uji F-statistik}

Tabel 9. Hasil Uji F-statistik

\begin{tabular}{lcccc}
\hline Df=(k-1;n-k) & $\boldsymbol{\alpha}$ & F-tabel & F-Statistik & Kesimpulan \\
\hline$(3 ; 39)$ & $5 \%$ & 2.85 & 22439.14 & Menolak $\mathrm{H}_{\mathrm{o}}$ \\
\hline Sumber: Output Eviews 8 & &
\end{tabular}

Tabel 9 menunjukkan bahwa nilai F-statistik sebesar 22439,14 dan nilai F-tabel sebesar 2,85. Nilai F-statistik ini lebih besar dibandingkan nilai F-tabel pada tingkat signifikansi $(\alpha)$ 5\%, sehingga $\mathrm{H}_{0}$ ditolak dan $\mathrm{H}_{\mathrm{a}}$ diterima. Dengan demikian dapat disimpulkan bahwa variabel UMP, PDRB, dan Investasisecara bersama-sama berpengaruh terhadappenyerapan tenaga kerja sektor industri di Pulau Jawa.

\section{- Interpretasi Metode Individual Fixed Effect}

Individual effect merupakan nilai individu masing-masing cross-section yang di dapat dari Fixed Effect Model. Dimana C melambangkan atau gambaran dari variabel lain yang tidak diamati dalam model regresi. Dari enam Provinsi di Pulau Jawa tersebut, DKI Jakarta memiliki effect tertinggi sebesar 9,544567. Hal ini menunjukkan bahwa UMP, PDRB, dan investasi tidak menjadi faktor utama dalam penyerapan tenaga kerjasektor industri di Provinsi DKI Jakarta. Dimana penyerapan tenaga kerjanya lebih banyak dipengaruhi oleh faktor lain seperti bidang konstruksi, sektor keuangan, real estate,jasa perusahaan, sektor perdagangan hotel dan restoran, serta faktor lainnya diluar variabel yang digunakan. Tanpa adanya variabel UMP, PDRB, dan investasi maka akan mampu meningkatkan penyerapan tenaga kerja sektor industri melalui sektor lain atau variabel ekonomi lainnya. 
Kemudian, dari enam Provinsi di Pulau Jawa tersebut ada Provinsi yang memiliki koefisien terendah yaitu Provinsi di Jawa Tengah dengan effect sebesar 7,886799. Dimana variabel UMP, PDRB, dan investasi mengalami penurunan sehingga menyebabkan penyerapan tenaga kerjanya lebih rendah dibandingkan dengan Provinsi lainnya di Pulau Jawa. Selain ketiga variabel tersebut yang menyebabkan rendahnya penyerapan tenaga kerja sektor industri di Jawa Tengah diakibatkan oleh kurangnya pembangunan ekonomi, penurunan permintaan jumlah produksi, sumber daya alam, dan faktor lainnya diluar variabel yang digunakan. Maka dari itu perlu adanya peningkatan UMP, PDRB, dan investasi untuk meningkatkan penyerapan tenaga kerja sektor industri di Jawa Tengah.

\section{PEMBAHASAN}

\section{Pengaruh Upah Minimum Provinsi (UMP)terhadap Penyerapan Tenaga Kerja Sektor Industri di Pulau Jawa Tahun 2010-2016}

Berdasarkan hasil estimasi pada Tabel 4.9 menunjukkan bahwa angka koefisien regresi variabel UMP adalah sebesar -0,874935dengan nilai probability sebesar 0,0000. Hal ini menunjukkan bahwa terdapat pengaruh negatif $(\alpha=0,05)$ dari variabel UMP terhadap penyerapan tenaga kerja sektor industri di Pulau Jawa tahun 2010-2016. Koefisien regresi variabel UMP sebesar -0,874935 juga menunjukkan bahwa setiap kenaikan UMP sebesar 1\%, akan cenderung menurunkan penyerapan tenaga kerja sektor industri di Pulau Jawa sebesar 0,87\%.

Hasil penelitian yang telah dilakukan mendukung temuan dari Wasilaputri (2016) dalam penelitiannya menemukan bahwa tingkat upah memiliki pengaruh terhadap penyerapan tenaga kerja, dimana setiap kenaikan $1 \%$ upah minimum provinsi akan diikuti oleh penurunan penyerapan tenaga kerja sebesar $0,12 \%$, ceteris paribus. Hasil ini menunjukkan kesesuaian dengan hipotesis penelitian yang menyatakan bahwa upah minimum provinsi berpengaruh terhadap penyerapan tenaga kerja. Hal ini disebabkan bahwa perubahan tingkat upah akan mempengaruhi tinggi rendahnya biaya produksi perusahaan. Naiknya tingkat upah akan meningkatkan biaya produksi perusahaan, yang selanjutnya akan meningkatkan pula harga per unit barang yang diproduksi. Sehingga banyak barang yang tidak terjual dan terpaksa produsen menurunkan jumlah produksinya serta turunnya target produksi mengakibatkan berkurangnya tenaga kerja yang dibutuhkan.

\section{Pengaruh Produk Domestik Regional Bruto (PDRB) terhadap Penyerapan Tenaga Kerja Sektor Industri di Pulau Jawa Tahun 2010-2016}

Berdasarkan hasil regresi menunjukkan bahwa angka koefisien regresi variabel PDRB adalah sebesar 0,561902 dengan nilai probability sebesar 0,0000. Hal ini menunjukkan bahwa terdapat pengaruh positif $(\alpha=0,05)$ dari variabel PDRB terhadap penyerapan tenaga kerja sektor industri di Pulau Jawa tahun 2010-2016. Koefisien regresi variabel PDRB sebesar 0,561902 juga menunjukkan bahwa setiap kenaikan 1\% PDRB akan cenderung diikuti oleh kenaikan penyerapan tenaga kerja sebesar $0,56 \%$, ceteris paribus. 
Hal tersebut didukung oleh hasil penelitian yang dilakukan oleh Dimas dan Nenik (2009) yang menyatakan bahwa PDRB memiliki pengaruh yang positif terhadap penyerapan tenaga kerja di DKI Jakarta, apabila PDRB meningkat $1 \%$ maka penyerapan tenaga kerja meningkat sebesar 1,23\%. Budi Utami (2009) mengatakan bahwa PDRB berpengaruhi positif terhadap kesempatan kerja di Kabupaten Jember tahun 1980-2007. PDRB merupakan cerminan dari pertumbuhan ekonomi (penambahan output yang dihasilkan), apabila PDRB meningkat maka jumlah kesempatan kerja akan semakin besar.

\section{Pengaruh Investasi terhadap Penyerapan Tenaga Kerja Sektor Industri di Pulau Jawa Tahun 2010-2016}

Berdasarkan hasil regresi pada Tabel 4.9 menunjukkan bahwa angka koefisien regresi variabel investasi adalah sebesar 0,821413 dengan nilai probability sebesar 0,0000. Hal ini menunjukkan bahwa investasi berperngaruh positif $(\alpha=0,05)$ terhadap penyerapan tenaga kerja sektor industri di Pulau Jawa tahun 2012-2016. Koefisien regresivariabel investasi sebesar 0,821413 juga menunjukkan bahwa setiap kenaikan investasi sebesar $1 \%$, akan cenderung menurunkan penyerapan tenaga kerja sektor industri di Pulau Jawa sebesar $0,82 \%$.

Hal ini didukung oleh penelitian yang dilakukan Roni (2010), bahwa investasi berpengaruh positif dan signifikan terhadap penyerapan tenaga kerja di Indonesia. Ketika terjadi kenaikan investasi sebesar $1 \%$ maka akan meningkatkan penyerapan tenaga kerja sebesar $0,01 \%$. Salah satu teori menjelaskan bahwa investasi bertujuan untuk mengganti dan terutama menambah barang-barang modal dalam perekonomian yang akan digunakan untuk memproduksi barang dan jasa di masa yang akan datang. Dengan kata lain, investasi berarti kegiatan perbelanjaan untuk meningkatkan kapasitas produksi suatu perekonomian dan untuk meningkatkan kapasitas produksi yang lebih tinggi diperlukan pula modal manusia yang mencukupi (Sukirno, 2003).

\section{Pengaruh UMP, PDRB dan Investasi secara Simultan terhadap Penyerapan Tenaga Kerja Sektor Industri di Pulau Jawa Tahun 2010-2016}

Berdasarkan hasil estimasi pada tabel 4.11 menunjukkan bahwa nilai F-hitung adalah sebesa r22439,14 dengan nilai probability sebesar 0,0000 dan tingkat signifikansi sebesar $(\alpha=0,05)$. Jika nilai probability lebih kecil dibandingkan dengan tingkat signifikansi yang digunakan $(0,0000<0,05)$ maka ini menunjukkan bahwa terdapat pengaruh yang signifikan dari UMP, PDRB dan investasi secara bersama-sama terhadap penyerapan tenaga kerja sektor industri di Pulau Jawa tahun 20102016. 


\section{SIMPULAN DAN SARAN}

\section{Kesimpulan}

Berdasarkan hasil uji regresi dan analisis data mengenai pengaruh Upah Minimum Provinsi (UMP), PDRB, dan Investasi terhadap penyerapan tenaga kerja sektor industri di Pulau Jawatahun 2010-2016, maka dapat diambil kesimpulan sebagai berikut:

1. Upah Minimum Provinsi (UMP) berpengaruh negatif dan signifikan terhadap penyerapan tenga kerja sektor industri di Pulau Jawa tahun 2010-2016.

2. PDRB berpengaruh positif dan signifikan terhadap penyerapan tenaga kerja sektor industri di Pulau Jawa tahun 2010-2016.

3. Investasi berpengaruh positif dan signifikan terhadap penyerapan tenaga kerja sektor industri di Pulau Jawa tahun 2010-2016.

4. Terdapat pengaruh yang signifikan dari UMP, PDRB dan investasi secara bersama-sama terhadap penyerapan tenaga kerja sector industri di Pulau Jawa tahun 2010-2016.

\section{Saran}

Berdasarkan hasil pembahasan dan kesimpulan yang telah diuraikan maka dapat disampaikan saran sebagai berikut:

1. Kebijakan Upah Minimum Propinsi (UMP) tetap diperlukan sebagai acuan penentuan upah yang layak bagi pekerja utamanya bidang industri akan tetapi perlu diimbangi dengan kebijakan lain seperti (1) kemudahan akses modal bagi pengusaha, (2) penurunan pajak output, dan (3) peningkatan produktivitas sehingga perusahaan mampu meningkatkan kapasitasnya dan meningkatkan produksi dengan biaya lebih rendah.Pemerintah harus berhati-hati dalam menaikkan upah minimum karena akan memunculkan penurunan penyerapan tenaga kerja. Berdasarkan hasil estimasi terlihat seperti itu, ada penurunan setiap persen dari setiap kenaikkan $1 \%$ dari upah minimum. Kedepannya harus berhati-hati, jika ingin menciptakan lapangan kerja baru. Penetapan upah minimum harus dilakukan secara tepat agar tidak merugikan tenaga kerja maupun pihak perusahaan.

2. Pemerintah daerah hendaknya mendorong dan memacu peningkatan produk domestik regional bruto disetiap sektor ekonomi sehingga penyerapan tenaga kerja meningkat. Produk domestik regional bruto berpengaruh positif terhadap penyerapan tenaga kerja, sehingga pemerintah perlu mengambil kebijakan dengan meningkatkan pendapatan daerah melalui pengembanganpengembangan kegiatan ekonomi yang mendorong meningkatnya output yang dihasilkan setiap provinsi seperti kegiatan sentra industri menurut wilayah, pengembangan berbasis peningkatan wilayah, dan pembangunan menurut karakteristik daerah.

3. Berdasarkan hasil penelitian yang menunjukkan bahwa investasi mempengaruhi penyerapan tenaga kerja, maka diharapkan Pemerintah untuk lebih menciptakan iklim investasi yang 
kondusif, seperti dengan melakukan promosi investasi ke luar daerah, dan mempermudah perijinan investasi. Hal ini bertujuan untuk lebih membuka dan mengembangkan kesempatan kerja baru, karena dengan adanya peningkatan kesempatan kerja baru diharapkan dapat meningkatkan penyerapan tenaga kerja serta mampu mengurangiangka pengangguran di Pulau Jawa.

\section{REFERENSI}

Adil. 2017. Analisis Faktor-Faktor Yang Mempengaruhi Penyerapan Tenaga Kerja Pada Sektor Industri Pengolahan di Provinsi Sulawesi Selatan Periode 2006-2015. Universitas Islam Negeri Alauddin Makassar.

Afrizal, Fitrah. 2013. AnalisisPengaruhInvestasi, BelanjaPemerintah Dan DanTenagaKerjaTerhadap PDRB DI Sulawesi Selatan 2001-2011. Makassar UniversitasHasanuddin.Skripsi(Tidakdipublikasikan)

Akmal, Roni. 2010. Analisis Faktor-faktor yang Mempengaruhi Penyerapan Tenaga Kerja di Indonesia. Skripsi. Fakultas Ekonomi Universitas Andalas. Sumatra Barat.

Chusna, A. 2013. Pengaruh Laju Pertumbuhan Sektor Industri, Investasi, dan Upah terhadap Penyerapan Tenaga Kerja Sektor Industri di Provinsi Jawa Tengah Tahun1980-2011. Journal of Economics Development. Universitas Negeri Semarang.

Dimas dan Woyanti, N. 2009. Penyerapan Tenaga Kerja di DKI Jakarta. Jurnal. Fakultas Ekonomi Universitas Diponegoro, Semarang

Gianie. 2009. Pengaruh Upah Minimum Terhadap Penyerapan Tenaga Kerja Berpendidikan Rendah. Tesis. Fakultas Ekonomi Universitas Indonesia.

Gindling T.H and Terrel Katherine. 2006. The Effect of Multiple Minimum Wage Throughout the Labour Market: The Case os Costa Rica. Journal of Labour Economics. 14 (2007) Hal. 485511

Gujarati, D.N., 2003. Basic Econometrics, McGraw-Hill. New York

Prihartanti, ED. 2007. Analisis Faktor-faktor yang Mempengaruhi Penyerapan Tenaga Kerja Sektor Industri di Kota Bogor [skripsi]. Fakultas Ekonomi dan Manajemen, Institut Pertanian Bogor 